Kraakenes, E., Tadayon A., and Johansen, A. (2019). "Comparing Lean Construction with Experiences from Partnering and Design-Build Construction Projects in Norway" In: Proc. $27^{\text {th }}$ Annual Conference of the International. Group for Lean Construction (IGLC), Pasquire C. and Hamzeh F.R. (ed.), Dublin, Ireland, pp. 937946. DOI: https://doi.org/10.24928/2019/0168. <Available at www.iglc.t>

\title{
COMPARING LEAN CONSTRUCTION WITH EXPERIENCES FROM PARTNERING AND DESIGN-BUILD CONSTRUCTION PROJECTS IN NORWAY
}

\author{
Eirik Kraakenes ${ }^{1}$, Allen Tadayon ${ }^{2}$ and Agnar Johansen ${ }^{3}$
}

\begin{abstract}
While the construction industry has long been known for conflicts and adversarial behavior, there are different delivery methods and approaches that have been developed to overcome these shortfalls. This paper aims to compare Design-Build (DB) and partnering through the lens of the lean construction approach. We examine to what extent partnering and DB are aligned with the lean construction's five big ideas and whether Design Build can be improved by adopting elements from partnering.

This study was carried out by conducting a literature study in combination with five case studies. The case studies were carried out via document review in addition, nine semi-structured in-depth interviews. The interviews were conducted with key personnel from target projects to understand the practitioner's point of view and the way that partnering and design-build are practiced in the industry.

In this paper, the authors conclude that partnering aligns to LC and its five big ideas to a high degree and that partnering includes embedded tools and mechanisms designed to meet what literature and interviews consider to be the main challenges with construction projects. It is also concluded that the use of DB can be improved by adopting suitable elements from the partnering approach.
\end{abstract}

\section{KEYWORDS}

Partnering, Design-Build, Lean Construction, Collaboration, Continuous improvement

\section{INTRODUCTION}

The benefits of collaborative, rather than adversarial, working relationships within the construction industry are well documented (Walker and Hampson 2002). However, the construction industry has historically suffered from conflicts and adversarial behavior that have led to reduced productivity (Aarseth., Andersen. et al. 2012, Mattias Jacobsson 2014). Recent research shows fragmentation, adversarial behavior and conflict equally describe the Norwegian construction industry (Haugseth, Lohne et al. 2014).

Although a number of causes may apply, Lahdenperä (2012) identifies the initial reason for low productivity to be the separation between the design and construction processes. Naoum (2003) also points out that the problem with construction efficiency and performance originates

\footnotetext{
${ }^{1}$ M.Sc. Independent researcher, 5093 Bergen, Norway, go2eirik@ hotmail.com

${ }^{2}$ Ph.D. Department of Civil and Environmental Engineering, NTNU, Norway, allen.tadayon@alumni.ntnu.no

${ }^{3}$ Dr. Philos, Senior research scientist, SINTEF Society, Norway, agnar.johansen@ sintef.no
} 
from the failure of traditional procurement methods, where the "low bid syndrome" is a determinant factor behind the commonly experienced adversarial behavior (Lahdenperä 2014). These failures, along with the fact that projects are becoming more complex and uncertain, result in a trend towards employing collaborative contracts (also called relational contracts) in the construction industry (Hosseini, Haddadi et al. 2017).

Despite the fact that the Design-Build (DB) contract evolved out of the need to integrate the design and construction processes, limited progress has yet been made towards facilitating collaboration in DB. According to Kalsaas, Hannås et al. (2018), a close relationship between the designer and the construction contractor appears to be central to project success. DB contracts therefore have the potential to benefit from including collaborative tools.

Meanwhile, relational contracts were introduced to the industry in order to develop better collaboration, increase efficiency and decrease conflict (Young, Hosseini et al. 2016, Hosseini, Windimu et al. 2017). While partnering is a form of relational contract that highly emphasizes collaboration in projects (Bellini, Aarseth et al. 2016), DB uses traditional procurement methods with an emphasis on awarding to the lowest bidder without introducing collaborative tools.

In this paper, we focus on two different objectives. First, we aim to see whether partnering and DB align with Lean Construction and its five big ideas. Second, by looking at five major construction projects in Norway, we explore whether DB contracts can be improved by adopting partnering elements.

To meet these objectives, the following research questions were formulated:

- Do DB and partnering align with LC's five big ideas?

- Whether DB contracts can be improved by adopting partnering elements?

The remainder of the paper is structured as follows. We first present the methodological choices made, then we discuss the theoretical basis for comparing DB and partnering with LC and its five big ideas. The last section discusses the findings in relation to the theory and suggests implications and directions for future research.

\section{METHODS}

In order to answer these research questions, a comprehensive analysis of relevant literature as well as a set of interviews were conducted to investigate the experiences of developers and contractors after completing projects using partnering and DB contracts.

The literature review was carried out in accordance with the procedures described by Blumberg, Cooper et al. (2014) to assure an in-depth knowledge of studied concepts. Five construction projects were then investigated through nine semi-structured, in-depth, casespecific interviews with key actors according to the methodological approach described by (Yin 2009). Each interview was conducted at the interviewee's office based on an interview guide that was established based on the research questions. Document study also was performed on all case projects prior to the interviews as a method of triangulation.

All interviewees were key personnel in the studied projects. The interviewees included four developers, three contractors and two consultants. They were chosen on the basis of their experience in project management as well as their thorough understanding and knowledge of the case project. It is noteworthy that one of the selected interviewees worked as a project manager on the very first partnering project in Norway.

Including both contractor and developer respondents assures balance in the interview findings. Interview duration was 1 to 1.5 hours. To increase data collection reliability, each interview was recorded, transcribed and then sent back to the interviewees for verification. The transcripts were later analyzed using a qualitative content-based analysis method. 
To draw the conclusions, data analysis progressed based on the methodology described by Creswell (2013) as follows:

1) Organizing and preparing raw data (transcripts, field-notes, images, etc.) for analysis

2) Reading trough all data

3) Coding the data (hand or computer)

4) Use the coding process to generate themes or description

5) Interrelating themes/descriptions

6) Interpreting the meaning of themes/descriptions

However, some limitations are still present in the research process. First, this paper only investigated five Norwegian construction projects. Second, there are not the same number of respondents from clients and contractors.

Table 1: Presentation of the five cases

\begin{tabular}{lccccc}
\hline Case/Status & Date & Building Size & Contract Type & Cost & Type \\
\hline Case 1/Delivered & 2017 & $9,800 \mathrm{~m}^{2}$ & Design-Build & $400 \mathrm{MNOK}$ & New building \\
\hline Case 2/Delivered & 2018 & $11,500 \mathrm{~m}^{2}$ & Partnering & $247 \mathrm{MNOK}$ & New building \\
\hline Case 3/Delivered & 2012 & $12,600 \mathrm{~m}^{2}$ & Partnering & $368 \mathrm{MNOK}$ & New building \\
\hline Case 4/Delivered & 2018 & $3,500 \mathrm{~m}^{2}$ & Design-Build & $116 \mathrm{MNOK}$ & New building \\
\hline Case 5/Delivered & 2016 & $1,250 \mathrm{~m}^{2}$ & Partnering & 65MNOK & New building
\end{tabular}

\section{THEORETICAL BACKGROUND}

In order to compare Partnering and DB using the lens of the five big ideas of Lean Construction, an exploration of the current theory on each topic was undertaken.

\section{Partnering}

Construction projects are becoming more complex, critical and uncertain (Wøien, Hosseini et al. 2016). These changes are creating a need for closer collaboration among the project participants. Literature argues that this need can be met through employing different forms of cooperative relationships. Although cooperative relationships can be discussed in terms of alliances, relational contracting and partnerships, in the construction industry, partnering is the most frequently discussed institutional form of cooperative relationship (Eriksson 2010).

Partnering also evolved due to the failure of the traditional procurement methods in meeting client needs and project objectives owing to increased project size and complexity (Naoum 2003, Wøien, Hosseini et al. 2016). It is worth noting that partnering is not suitable for all kinds of projects. In small, one-off, less complex projects which are of low strategic importance, the set-up costs simply do not justify an extensive collaborative approach (Eriksson 2010).

While there is a broad agreement about the overall philosophy of partnering (Bresnen. and Marshall. (2000), it is generally agreed that no unified understanding of the partnering concept exists (Lena E.Bygballea 2010, Hosseini, Wondimu et al. 2016). Even though many definitions have been developed, there is no universal definition of the partnering concept (Eriksson 2010). For the purpose of this paper, we have chosen to use one of the first and most widely used definitions of partnering, provided by the Construction Industry Institute (CII) in 1991.

This definition of partnering is provided as follows: "A long-term commitment by two or more organizations for the purpose of achieving specific business objectives by maximizing the effectiveness of each participant's resources. This requires changing traditional relationships to a shared culture without regard to organizations' boundaries. The relationship is based on trust, dedication to common goals and an understanding of each other's individual expectations 
and values. Expected benefits include improved efficiency and cost-effectiveness, increased opportunity for innovation, and the continuous improvement of quality products and services." $(C I I, 1991)$

By establishing relations and a pain and gain sharing mentality, partnering aims to accomplish a positive environment in the project and achieve success for all participants (Naoum 2003).

While partnering projects may share the partnering label, they can use different sets of hard elements (Hosseini, Windimu et al. 2017). The literature distinguishes between hard and soft elements in managing projects. Hard elements include elements that either are directly regulated by the contract or have their roots in the procurement process. Soft elements, on the other hand, are not tangible and are usually related to the relationships between the people in the project (Wøien, Hosseini et al. 2016). Having a real pain/gain sharing mechanism and the use of a legally binding partnering charter make up the most important hard elements. Trust, communication, long-term commitment and cooperation comprise the most important soft elements (Eriksson 2010).

\section{DESIGN-BUILD (DB)}

$\mathrm{DB}$ is a project delivery method (PDM) where the owner signs a contract with a single contractor that undertakes all or significant parts of the design and construction for the owner (Xia, Molenaar et al. 2013, Rolstadås, Olsson et al. 2014, Standard.no 2018). By transferring the authority for the design and construction to the contractor, DB projects demand a lower level of involvement from the owner (Lædre 2012).

Although prior research reveals the use of DB contracting in public procurement gained its popularity (D. Songer and Molenaar 1997), more recent research demonstrates that DesignBuild contracts are still increasing in number as the construction industry seeks less adversarial and more integrated project procurement strategies (Lam, Chan et al. 2012). Despite the fact that DB contracts have been used worldwide for more than 40 years Lam., Chan. et al. (2007), DB contracts are still relevant and in high demand today.

Perhaps the greatest motivation and benefit for an owner to use DB is to reduce both the duration of the project as well as design errors by integrating design and construction activities (Koch., Gransberg. et al. 2010). Usually in DB, all responsibility for risk and uncertainty in the areas of time, cost and quality is transferred to the contractor, which also becomes responsible for the interfaces between the contracts of various subcontractors (Lædre 2009).

Commonly, the DB contract is based on a description of the product's function rather than on a complete and specified design for the construction (Aandahla., Wondimu. et al. 2017). For the contractor, DB gives greater freedom to choose the appropriate set of solutions, which fits with the contractor's equipment and expertise (Lædre 2009). The contractor's freedom to choose can, in fact, lead to a disadvantage for the owner, since the contractor might have a strong pressure on price and may be inclined to compromise on quality without the owner having much opportunity to influence the construction along the way (Rolstadås, Olsson et al. 2014).

\section{LEAN CONSTRUCTION (LC) AND ITS FIVE BIG IDEAS}

The success of lean as a management philosophy in manufacturing has inspired its adoption into other industries and particularly into the construction industry (Howell 2014, Young, Hosseini et al. 2016). Lean construction has over the last two decades gained widespread interest from academics and practitioners within the construction industry (Bygballe and Swärd 2014). However, there is still no agreed upon definition of lean construction according to Mossman (2018), who goes on to argue that perhaps the easiest way to think about lean construction is in terms of its purpose. 
According to Howell (2014), lean construction provides an approach to modern construction that significantly improves collaboration, innovation, delivery control and quality within projects. Lean construction has been reported to create substantial improvement for those construction firms that adopt it (Bygballe and Swärd 2014). Benefits of using lean construction include shorter delivery time and high project performance (Locatelli, Mancinin et al. 2013, Young, Hosseini et al. 2016).

With the aim of reforming the construction industry, the Lean Construction Institute (LCI) (www.leanconstruction.org) launched the five big ideas in 2004 on how generally to organize and implement building and construction projects. LCI claims that there is a solid historical foundation for the ideas that have been developed in connection with the construction of hospitals in California (Kalsaas 2017).

According to Macomber (2010), the Five Big Ideas can transform projects. The "Five Big Ideas" examines five areas in which project progression and innovation can be optimized by including lean principles (Howell 2014). Together they form the foundation for innovating project delivery systems and approaches. Companies around the world that have adopted one or more of these ideas to improve their practices report significant gains.

The Five Big Ideas consist of the following:

1. Collaborate - really collaborate - throughout design and execution. Close collaboration between teams early in the project development process significantly reduces scope changes later in the project.

2. Increase relatedness among all project participants. Establishing trust and openness, willingness to innovate and ability to learn improves relationships.

3. Projects are networks of commitments.

Commitments bind teams and their members within projects, allowing for project direction in real time.

4. Optimize the project, not the pieces.

Collaboration and optimization at a project level reduce conflict and disputes caused by push management and productivity management at the task level.

5. Tightly couple action with learning.

Continuous improvement can more readily occur when these elements are combined.

These ideals outline the context and circumstances necessary to facilitate the deployment of lean construction. Combining common objectives and relational behavior aligns stakeholder sentiment and generates high value-add procurement strategies (Howell 2014).

\section{FINDINGS AND DISCUSSION}

This discussion presents the author's interpretation of the studied literature and collected data through interviews and document studies.

Table 2 shows how many of the five big ideas were present for each case and how the contractor delivered on cost, time and quality. 
Table 2: Presentation of findings for the five cases

\begin{tabular}{lll}
\hline Cases & LC five big ideas used & Comments \\
\hline Case 1 & Only 3 & Delivered on time and quality with cost overrun \\
\hline Case 2 & $(1,2,3,5)$ in use & Delivered on time, cost and quality \\
\hline Case 3 & $(1,2,3,5)$ in use & Innovative project - Delivered on time, cost and quality \\
\hline Case 4 & $(1,2,3,4)$ in use & Delivered on cost, quality and time. \\
\hline Case 5 & Only 3 (and weak) & Disaster project - Delivered on quality, cost and time overrun. \\
\hline
\end{tabular}

\section{COLLABORATE - REALLY COLLABORATE - THROUGHOUT DESIGN, PLANNING} AND EXECUTION

According to Howell (2014), close collaboration between teams early in the project development process will significantly reduce scope changes later in the project.

One of the purposes of partnering is to help create more collaboration in projects. Partnering consists of hard elements such as early involvement of contractors (ECI), which facilitates and creates a close collaboration between the project participants, while other elements such as continuous workshops allow the participants to focus on continuously evaluating relationships and strengthening teambuilding.

Findings from the interviews in this study support the literature and demonstrate close collaboration in partnering projects. Respondent 8 stated, "Yes, in partnering it is collaboration from day one and a better working environment. There are fewer conflicts due to the sharing of risk between developer and contractor." Moreover, according to respondent 3, "Changes are handled in partnering projects where the contractor, subcontractors and developer are involved in defining the project in parallel with the execution of the project. You don't have the ones that oppose the project." The latter finding highlights the attitude that is achievable in partnering projects when project teams gather and collaborate as a whole by committing and working towards a mutual goal with shared risk.

On the other hand, the respondents believe that collaboration in DB contracts can be challenging. According to Lædre (2012), in DB contracts the contractor can choose designers and subcontractors who have collaborated well with them on previous contracts and who are familiar with the contractor's working methods, but there are no collaborative tools or measures to guarantee the desired level of cooperation. This finding highlights that projects in general could benefit from incorporating collaborative tools.

\section{INCREASE RELATEDNESS AMONG ALL PROJECT PARTICIPANTS}

Increased relatedness between the project participants is suggested as critical in establishing fundamental relational elements such as trust, openness, willingness to innovate and ability to learn. These factors will consequently affect the growth of relational contracting and largely dictate the culture of the project, whether it is adversarial or non-adversarial (Howell 2014).

With key partnering elements consisting of trust, openness, relationship-building activities and mutual goals and objectives (Nyström 2005), partnering aims to establish a good relationship with a pain and gain sharing mentality. Partnering's use of collaborative tools and risk sharing can achieve a positive environment and a successful outcome for all the project participants. This practice can facilitate increased relatedness more naturally when the project participants are working towards the same direction toward mutual goals.

Unlike partnering, the DB contract is formulated in a simpler format and does not contain any specific hard elements to facilitate increased relatedness between the project participants, leaving it up to the project individuals in DB contracts to establish how much they are willing to relate to the other project participants. As one of the interviewees stated, "The collaborative outcome and increased relatedness between the project participants will depend more on whether you have the right people in the project." This finding showcases that projects need a 
structured way to facilitate collaboration and develop increased relatedness among the project participants.

\section{ProjectS ARE NETWORKS OF COMMITMENTS}

According to Howell (2014), the five big ideas highlight that an effective project consists of a network of commitments rather than just a process or value stream. Furthermore, he states that commitments are the fibers that bind teams and team members within projects, allowing for project direction to occur in real time.

Partnering consists of elements such as mutual objectives, partnering charter and agreement, all of which aim to align the project participants' (developer, contractor and consultant) goals. This observation was highlighted by one of the respondents when he stated, "in a project in which the project's participants meet and together develop mutual objectives and goals for the project, there will be absolutely a better commitment."

On the other hand, the main commitment in a DB contract is for the contractor to deliver the project according to the agreed-upon price (lowest bid) at the scheduled time and with reasonable quality.

DB contracts have limited interaction between the developer and contractor compared to partnering projects. The usual ongoing commitment in DB contracts could be limited to achieving milestones within a certain time and cost, whereas penalties such as malus are important tools for the developer to use against the contractor to make sure the project is following the scheduled plan. Furthermore, according to respondent 3, "in DB contracts it is often that the contractor reduces the quality of material and the equipment to deliver a minimum of what is required in the contract, regardless of whether it is a minimal cost to get double the quality."

\section{OPTIMIZE THE PROJECT NOT THE PIECES}

According to Macomber (2010), pushing for high productivity at the task level may maximize local performance but it may increase project duration, complicate coordination and reduce trust. However, collaboration and optimization at the project level can reduce conflict and disputes caused by push management (Howell 2014).

One of partnering's main ideas is that the early involvement of contractors and key players in the project provides greater opportunities for savings, value creation and project optimization (Brodtkorb 2017). Incorporating contractor's expertise, specifically on constructability, in an early project stage can lead to decreased design cost, increased efficiency, better solutions and building trust (Hosseini, Windimu et al. 2017).

According to respondent 6, "Cooperation in the early phase of the project is more important, and more and more people in the industry believe this. It is important because you get the competence that is valuable in order to optimize your project right from the start." This early involvement provides the opportunity to involve the contractor's area of competence early and throughout the execution of the project and not just for individual task and activities. This involvement will be supported by mutual objective-setting and is best for facilitating collaboration and optimizing the project as a whole rather than just the various pieces.

One of the DB contract's great strengths is that it collects planning, design and execution together. Conducting both design and construction opens for a two-way experience transfer between designers and executives (Lædre 2012). Integration of design and construction reduces duration and leads to optimizing the project trough buildable solutions. Furthermore, the DB contractor can choose project designers and subcontractors with whom they have cooperated well on previous projects. By having already established a group of personnel that understands the working methods and cooperates well, participants find that less time is spent on conflicts.

\section{TIGHTLY COUPLE ACTION WITH LEARNING}


With respect to the fifth idea, Macomber (2010) states that continuous improvement of cost, schedule and overall project value is possible when project performers learn in action, while Howell (2014) emphasizes regular inspection and control for identifying mistakes to reduce the risk of future re-work.

Partnering conducts continuous workshops throughout the project, which plays an important role in continuous improvement and implementation of new procedures. Further, it ensures that participants are following procedures and monitoring team goals and stakeholders' commitment (Hosseini, Windimu et al. 2017). Partnering also uses measurement during the project. Results and process measures are "hard" measures based on performance and progress, while relationship measures are often called "soft" measures and are used to track team activities and the efficiency of the partnering team (Crane, Felder et al. 1999).

Although construction work is often hidden and difficult to inspect (Kadefors 2004), partnering projects do not emphasize client inspections. And while most clients rely heavily on extensive end inspections of the finished work, in partnering projects, it is better to rely more on the contractors' self-control and execute limited random end inspections (Eriksson 2010).

The DB contract does not include any specific elements like continuous workshops, thus relying more on control and inspection to reveal mistakes. However, the control element could pose a challenge for the owner. According to respondents (1 and 3), "often in DB contracts and other projects, it's about sweeping the dirt under the carpet," making it challenging to control and reveal mistakes. Although DB contracts may use prequalification to secure expertise, its recommended to include operational responsibility of the contractor to secure quality and reduce mistakes.

\section{CONCLUSION}

This research has two purposes: first, to see how much DB and partnering are aligned to LC's five big ideas on how to deliver projects, and second, to reveal if DB contracts can adopt partnering elements. The overall conclusion by considering (RQ1) is that partnering does in fact align to LC's five big ideas of project delivery. DB, on the other hand, aligns to a low degree. While DB contracts have integrated the design and construction elements, they lack the inclusion of a structured way of ensuring more collaboration in DB projects. As prior research shows, a positive working relationship between designer and contractor is essential to project success. Without collaboration tools, there is no structured way to facilitate a positive relationship between the project participants.

The answer to the second research question (RQ2) is that DB contracts absolutely could benefit from adopting partnering elements. We suggest including collaborative tools, since this addition is possible without interfering with the DB contract structurally. Other elements also could be beneficial, depending on the project characteristics and client's objectives. As such, the DB contract could remain the same while incorporating partnering methods and tools in its PDM. Based on the findings from the literature study and interviews, it appears that change orders, conflicts, lack of trust, maintaining proper communication and developing mutual goals represent some of the biggest challenges with construction projects. Considering these issues, partnering embeds tools and mechanism for meeting these challenges whereas DB does not. However, DB can benefit from the successes of partnering and practitioners can adopt elements of partnering to overcome DB's shortfalls. What has been highlighted as the partnering's biggest challenge is the limited understanding of practitioners on what partnering is and how it should be practiced. Therefore, this study suggests more research on the practical side of implementing partnering and developing a systematic way to employ partnering in construction projects. 


\section{REFERENCES}

Aandahla., S. H., et al. (2017). "Managing the room of maneuver in design build contracts - a comparative study of Norwegian road projects." Procedia Engineering (2017): p. 187 194.

Aarseth., W., et al. (2012). ""Practical difficulties encountered in attempting to implement a partnering approach"." International Journal of Managing Projects in Business Vol.5(2): p. 266-284.

Bellini, A., et al. (2016). "Effective knowledge transfer in successful partnering projects." Energy Procedia, 2016. 96: p. 218-228.

Blumberg, G., et al. (2014). Business research methods McGraw-Hill Higher Education; 3 edition.

Bresnen., M. and N. Marshall. (2000). "Partnering in construction: a critical review of issues, problems and dilemmas." Construction Management \& Economics 18(2): p. 229-237.

Brodtkorb, H. C. (2017). Veileder om partnering : en gjennomføringsmodell og samarbeidsform i et bygge- eller anleggsprosjekt som er basert på tidlig involvering av partene, dialog, tillit og åpenhet. Oslo, EBA.

Bygballe, L. E. and A. Swärd (2014). IMPLEMENTING LEAN CONSTRUCTION: A PRACTICE PERSPECTIVE. Proceedings IGLC-22. Oslo, Norway

Crane, T., et al. (1999). "Partnering Measures." JOURNAL OF MANAGEMENT IN ENGINEERING 15(2).

D. Songer, A. and K. Molenaar (1997). "Project Characteristics for Successful Public-Sector Design-Build." Journal of Construction Engineering and Management 123.

Eriksson, P. E. (2010). "Partnering: what is it, when should it be used, and how should it be implemented?" Construction Management and Economics, 2010. 28(9): p. 905-917.

Haugseth, N., et al. (2014). Partnering in Statsbygg. Proceedings IGLC-22. Oslo, Norway, 2527 June 2014 p 1343-1356.

Hosseini, A., et al. (2017). Relational base contracts - Needs and trends in Northern Europe. ProjMAN. Barcelona, Spain, Procedica Computer Science 121: p. 1088-1095.

Hosseini, A., et al. (2017). "Project Partnering in the Construction Industry: Theory vs.

Practice." The Engineering Project Organization Journal Volume 8 (January 2018): p. 13-35.

Hosseini, A., et al. (2016). "Project partnering in Norwegian construction industry." Energy Procedia, 96: p. 241-252.

Howell, J. (2014). "Lean construction." Public Infrastructure Bulletin 1(9): p. 5-29.

Kadefors, A. (2004). "Trust in project relationships: inside the black box." International Journal of Project Management 22(3): p. 75-82.

Kalsaas, B. T. (2017). Lean Construction. 1st edition. Fagbokforlaget, Bergen: p. 27-28.

Kalsaas, B. T., et al. (2018). Transformation from design-bid-build to design build contracts in road construction. IGLC. Chennai, India: p. 34-45.

Koch., J. E., et al. (2010). Project Administration for Design-Build Contract. A Primer for Owners, Engineers, and Contractors, ASCE p: 3-4.

Lædre, O. (2009). Kontraktstrategi for bygg- og anleggsprosjekter, 1st edition Tapir akademisk forlag, $\mathrm{p} 71$.

Lædre, O. (2012). Gjøre det selv eller betale andre for jobben, Concept Temahefte Nr. 3, Concept programmet, Trondheim, Norway p 11.

Lahdenperä, P. (2012). "Making sense of the multi-party contractual arrangements of project partnering, project alliancing and integrated project delivery." Construction Management and Economics Volume 30(1): p. 59-79. 
Lahdenperä, P. (2014). Rationalising public procurement of complex construction projects by the price component selection. Book of proceedings, the 6th International Public Procurement Conference (IPPC). Dublin, Ireland: p. 429-443.

Lam, E., et al. (2012). "Why is Design-build commonly used in the public sector?" Construction Economics and Building 3(1): p. 53-62.

Lam., E. W. M., et al. (2007). "An Empirical Study on the Problems of Running Design and Build Projects in Construction." International Journal of Construction Management 7: p. 1-15.

Lena E.Bygballea, M. J., AnnaSward (2010). "Partnering relationships in construction: A literature review." Journal of Purchasing \& Supply Management 16: p. 239-253.

Locatelli, G., et al. (2013). "Improving projects performance with lean construction: State of the Art, Applicability and Impacts." Organization, Technology and Management in Construction 6(2): p. 775-783.

Macomber, H. (2010). "Putting the Five Big Ideas to Work." 2010, from http://www.lcicanada.ca/wp-content/uploads/2015/12/Five-Big-Ideas.pdf.

Mattias Jacobsson, T. L. W. (2014). "Partnering hierarchy of needs." Management Decision 52(10): p. 1907-1927.

Mossman, A. (2018). What Is Lean Construction: Another Look - 2018. 26th Annual Conference of the International Group for Lean Construction. Chennai, India: p. 12401250.

Naoum, S. (2003). "An overview into the concept of partnering." International Journal of Project Management 21: p. 71-76.

Nyström, J. (2005). "The definition of partnering as a Wittgenstein family-resemblance concept." Construction Management and Economics 23(5): 473-481.

Rolstadås, et al. (2014). Praktisk Prosjektledelse, Fra idé til gevinst, 1st edition. Fakbogforlaget p. 301.

Standard.no (2018). "NS 8407 og NS 8417 Standardkontraktene for totalentreprise og totalunderentreprise."

Walker, D. and K. Hampson (2002). Procurement Strategies: A Relationship-based Approach, 1 st edition, Wiley-Blackwell.

Wøien, J., et al. (2016). "Partnering Elements' Importance for Success in the Norwegian Construction Industry." Energy Procedia 96: p. 229-240.

Xia, B., et al. (2013). "Determining the optimal proportion of design in design-build request for proposals " Journal of Construction Engineering and Management 139(6): 620-627.

Yin, R. K. (2009). Case Study Research, Design and Methods, $4^{\text {th }}$ edition, Thousand Oaks, California, SAGE.

Young, B., et al. (2016). "The characteristics of Australian infrastructure alliance projects." Energy Procedia 96: p. 833-844.

Young, B. K., et al. (2016). Project Alliances and Lean Construction Principles. Proceeding IGLC-24. Boston, USA: p. 33-42. 